\title{
Dangers of Forming New Federal Regions in Iraq on Ethnic-Sectarian Bases
}

\author{
Murad A. Abbas, Radhi S. Jassam \\ Department of Political Thought, International Studies, University of Baghdad, Baghdad, Iraq \\ Email: aliabbasmurad@yahoo.com, sameerjassam@yahoo.com
}

Received 17 June 2016; accepted 19 July 2016; published 22 July 2016

Copyright (C) 2016 by authors and Scientific Research Publishing Inc.

This work is licensed under the Creative Commons Attribution International License (CC BY). http://creativecommons.org/licenses/by/4.0/

\section{(c) (i) Open Access}

\begin{abstract}
This paper is an objective opinion of Iraqi professors, specialized in political science. It is concerning the application of federalism in Iraq. It deals with the problems created by the adoption of the federal system in Iraq after the year 2003. Iraqis are not yet prepared to work through such system, which has not developed through their own needs. After they will be finished with the ISIS, they will have to expand the application of the federal system throughout Iraq. Such an act will create many problems. If the new federal regions formed on a sectarian principle, this would cause higher instability in Iraq. In order to avoid having such problems, we need to strengthen the federal government through granted it more powers and authorities, so that, it could absorb peacefully the problems of the formation of new federal regions.
\end{abstract}

\section{Keywords}

State, Federal System, Federalism, Federal Government, Administrative Federalism, Kurdistan Federal Region, Democracy

\section{Introduction}

In 1921, Iraq was founded by the British mandated authority as a unitary state composed of three major areas (Willayat = Baghdad, Mosel, Basra). These three willayates had no common interest in forming such a state. Administratively, they were divided into smaller units called governorates, and were centrally ruled from Baghdad. Therefore, they had no opportunity to build their own local authority, and to manage the affairs of their governorates, to reflect their ethnic, religious and sectarian diversity. However, in 2003, the new Iraq had been founded with the intention of becoming a federal state in order to reflect its diversity. In 2005, Iraq had become officially a federal system after the adoption of the permanent constitution. It has been formed from the Kurdis- 
tan region, which has become constitutionally a federal unit. The rest of Iraq stayed as it was composed of 15 governorates, having the right to form its own federal units.

We believe that, the problem of forming new federal units in Iraq, could lead to the division of Iraq at least into three major units. This fear based on facts existed on the Iraqi ground \& supported by local \& regional forces. We believe that, forming new federal units based on ethnic, religious or sectarian principles would not lead to the stability of Iraq as a state. What might lead to a real stability in Iraq would be, forming those new federal units on an administrative principle with a strong federal government. Strong federal government means, it must have the rights \& capabilities to keep the unity \& stability of Iraq.

In 2013, there was an attempt by the local authorities of Sallahedeen province to form its own federal unit, but it was faced with rejection from the federal government. The rejection was based on the allegation that, this federal unit might lead to the division of Iraq. At the present, Iraq was in a state of war against the ISIS, when this war would end in the defeat of ISIS, there would be a need to form new federal units especially in the areas that were under the control of ISIS. The future stability of the political system in Iraq requires the formation of new federal units.

This paper is not intended to oppose the application of federal system throughout Iraq, but it attempts to clarify the problems facing the formation of new federal units similar to the one in Kurdistan Iraq. It is intended \& attempted to be academic, objective, impartial point of view, which is expressed by Iraqi university professors. This paper calls for the application of the federal system based on the realization of its importance \& the necessity to adapt in accordance with the facts of the reality of Iraqi political, social \& economic situation.

We believe that, one of the most important problems facing the applications of federalism in Iraq is the lack of conviction by many of the parties involved in the federal authority. If there was a real conviction of those parties, the regional authority of Kurdistan would not loom for secession whenever they face the problem with the federal government.

\section{Regional Federalism in Iraq}

One of the basic conditions for the success of the formation of states to their constitutional system requires studying the experience of other states (Blindenbacher \& Ostien, 2005: p. 54). Iraqis through their adoption to the federal system \& the experience of building it, they should not only learn from those experiences, but they should first admit the great complexity of building their own federalism. The suffering of this experience has resulted from the problem of mixing \& the interaction between the internal factors such as (ethnic, cultural, political \& economic), \& the external regional (Arab \& non-Arab) \& the international. We have noticed through the context of this overlap, \& through the experience of building the first federal region in Iraq, that, Iraqi Kurds, on the one hand, since the creation of the Iraqi state at the end of the second decade of the 20th century, have suffered from many problems \& difficulties with the succeeding central governments. On the other hand, and for fair and objective reasons, they have caused so many problems \& difficulties to those governments. No one could deny the fact that, the relationship between those two parties was mostly built on the action of one party \& the reaction of the other one, the attempt of each party to take advantage of the problems of another party through making some pressing demands \& try as much as they can to acquire some benefits \& concessions. Therefore, Iraqi Kurds in a very natural human behavior that, they would not be blamed for, have attempted to employ the new circumstances that existed after 9 April 2003 to serve their cause \& pushing the new political system to adapt with the federal principles, according to the following realistic facts:

1. The distinct ethnic \& linguistic formation from the rest of the components of Iraqis society.

2. They make the greater majority within a unified geographic area that is located in the northeast of Iraq.

3. They were able with the help of the United States \& the United Nations (through what used to be called Operation Provide Comfort) to enjoy a great deal of autonomy outside the control of the central government in Baghdad after the end of the 1991 war.

Since Iraqi permanent constitution of the year 2005, asserted that, the new Iraqi state is going to be a federal state \& confirm the formation of the Kurdistan region as a federal region, never clarify the natural and legal bases for the formation of such a region, this fact makes us believed that, the bases were made on the followings:

1. The constitutional naming of the region as (Kurdistan region) means the (Land of Kurds).

2. The insistence of the political \& societal Kurdish parties on annexing a new land area and adding it to the 
region, including Kirkuk \& other parts from others Iraqi governorates. The Kurds consider those areas (withholding areas), the other Iraqi political \& societal parties call it (disputed areas). The Kurds parties on their pronounced fact have made this presumption that; those areas are composed of the majority of the Kurds population.

What has been said, would lead to the fact, that, the federal region of Kurdistan in Iraq is the type of dual federation based on racial-ethnic (Kurdish nationalism) \& regional-geographic (the region North East of Iraq), which would make it at the same time a mixture of (Ethno-Region federalism). This has known as a type of federalism, which recognizes the different ethnic societies as a component of the system.

\section{The Problems of Expanding the Application of Regional Federalism in Iraq}

The application of regional federalism in Iraq, weather in the case of Kurdistan region or the future formed regions is facing two basic problems:

The first problem. The common misunderstanding among most of the political \& social Iraqi parties to federalism as a thought $\&$ project. Most of them believe that, it could be used as a cover to secession. IF this common misunderstanding is mistaken concerning the federal project $\&$ their reality of aiming at achieving the political \& societal unity of the state \& preserving it through the federal system as a guarantor to the diversity within the framework of unity. It should be right on the other side as much as it is related to the Iraqi reality which is full of such factors \& circumstances which do not help in preventing such negative understanding to federalism \& its potential objectives.

The second problem. It is the federal region of Kurdistan is not the only federal region to be build upon for the future federal regions in Iraq. There are many projected federal regions presented by many different political parties to be formed in the middle \& south of Iraq. Those regions would not be similar in its formations \& basics to the federal region of Kurdistan. Those federal projects are too many \& would be conflicting with one another, \& would not aim at gathering the Iraqi Arabs in one geographic region similar to the one in Kurdistan, where the two federal regions are based on a dual base (political regionalism, ethnic regionalism).

We believe that, the problem with the projected federal regions, is that, those parties are going to build those federal regions in accordance with their sectarian borders and not their ethno-national borders like what their Kurdish brothers have in the north of Iraq. We should not forget the diversified nature of the inhabitants of such regions as Basra, Unbar, Salahaldeen \& Kirkuk, which is highly mixed concerning their ethnic, religious \& sectarian identities. This fact has encouraged many interested Iraqi \& foreign parties to work hard to build such a region according to what they believed in, especially their sectarian interest. The details of such picture are affirmed if we remember that Mr. Paul Bremer, the first ruler of Iraq after the invasion of 9th April 2003, had announced that, the social, political reality of Iraq, has changed and Iraqis are divided into (Shies, Sunny, \& Kurds).

The forces, who have participated in administering Iraq since then, are divided \& were formed on ethno-sectarian facts. Iraqi components have been described since then as (Shies, Sunny \& Kurds). Therefore, we believe that such classification does not match the reality of Muslims in Iraq, neither for Arabs nor for Kurds. This fact finds its explanation in the reality that Muslim Kurds are too, divided into Sunny \& Shies, but the majority of them are Sunny. The Arab Muslims also divided into Sunny \& Shies, but the majority of them are Shies. There are also minorities living in Iraq such as the Turkmen who are divided into Sunny \& Shies too. There are also other religious minorities such as the Kuldo-Assyrian, the Eyzedeen, Shabak \& Sabena. Therefore, classifying Iraqis into Shies, Sunny \& Kurds, ignores the reality we have discussed above $\&$ deny the existing reality of Iraq.

This evokes in our minds the state of the Chuckslovakian union, which was formed from two different ethnicities. This type of a federal system clarifies the problems and tensions, which might be created by forming such a system. This cumulative polarization ended when Chuckslovakia became two independent states in 1993, without even having a referendum asking what the people would like to (Watts, 2005: pp. 43-45). These examples clarify the specific problems, which would result out of the formation of such unions \& the dynamic process represented by the cumulative dual polarization, the speed which division between those two components would take place, when the political leaders believe it would be beneficial to their own interests.

Recalling such cases pushes us to pay more attention to the percentages \& the methods of distributing authorities in Iraq between the federal government \& the government of Kurdistan region \& other local authorities. 
According to the scientific fact, which asserts that, the higher the degree of harmony among the societal components of the state, the higher the authorities granted to the federal government. The higher the degree of diversity, the higher the authorities granted to the regions or any other units comprising the federal system. It is desire to give the federal government more authorities, so it would able to resist all attempts to divide the state \& even attempts to weaken it.

Since the process of rebuilding state in Iraq after 2003, has suffered from problems similar to the ones discussed above, especially the problem of identity, corruption, \& the political quota. Therefore, the danger of the cumulative polarization (Ethnic, Religious \& Sectarian) would be present with its negative consequences especially if the future federal regions would be formed on those bases. This kind of formation would threaten not just the stability of the Iraqi state \& the continuation of its federal system, but it also would threaten its existence \& survival as a unified state.

\section{The Risks of Broadening Regional Federalism in Iraq}

The present reality of Iraq has been dominated by the following facts:

1. The ability of international \& some of the active regional powers to have a negative, deep \& broad influence on the political process in Iraq including those issues related to federalism.

2. The different positions of the neighboring countries of Iraq from its new political system, policies, regional \& international relations.

3. The different ethnic \& sectarian affiliation of the neighboring countries.

4. The different objectives of the neighboring countries of Iraq, concerning its present $\&$ future.

5. The different vision of the neighboring countries of Iraq, concerning the nature of its present \& future of its regional \& international relations.

6. Likely, the future formation of any new federal region other than Kurdistan region will be based on the regional-geographical basis. This new region will definitely be based on an undeclared ethnic, religious or sectarian basis, the probability of the sectarian basis. If that would happen, it would definitely push any ethnicity or Iraqi sect, Muslim or non-Muslims other than the Kurds, to demand to have its own federal region. Forming such regions might lead to secession with the help of some forces from regional countries. This would lead to the following present $\&$ future consequences:

a). The impact of international \& regional powers on those new regions \& the probability of having a harmony of interest concerning the secession out of Iraq.

b). The weakness of the federal government $\&$ its inability on making $\&$ implementing decisive $\&$ crucial decisions because of the impact of the ethnic, religious or sectarian, principles \& the regional \& international intervention in its affairs.

c). The ambition of some Iraqi politicians to preside over those federal regions demanded to be set up. Such an event probably might lead with the support of regional countries into transforming these regions into independent states.

d). The establishment of any new federal regions in Iraq on a unilateral basis (ethnic, religious or sectarian) or complex, beside the federal regional of Kurdistan which was established on a dual basis (ethnic-regional), will include the danger of a wide intervention of the regional \& international powers in the internal affairs of Iraq. Once through its direct interventions in the affairs of those regions, the other through its interventions directly in the affairs of the federal government under the pretext of its responsibility for the defense of the territory of their sons in ethnicity, religion, or sect \& protect their interest. Such an event would lead to the declaration of one of the regional or international powers its guardianship on any of these newly formed regions. Such an action would push other states to declare an opposite declaration and impose its own guardianship on another federal region that in turn would transfer Iraq into an arena of struggle among the regional \& international powers that would definitely hurt Iraqi national interests.

e). The establishment of any new federal region in Iraq on unilateral bases, besides the federal regional of Kurdistan, would involve the danger of weakening the Arabs as a social component to the benefits of unifying \& strengthening the other ethnic components of Iraq. Such an event would provoke the feeling of fear in the Arabs \& push them to act in away might destroy the state of peaceful coexistence \& run the vehicle of violence \& counter violence.

f). The establishment of any new federal region in Iraq on unilateral bases, besides the federal regional of 
Kurdistan, would involve two dangers:

The first danger. Each sect might have its own canton within the Iraqi state (Amel, 1989: p. 41), such an event would reflect the (stalemate) democratic model of federal Iraq in the form of too many sectarian cantons interacting with each other on the stalemate $\&$ not settlement base. This danger would be coupled with the problem of rising weakness of national identity \& the problem of working on forming a (New Middle East) through the partition of each state into many mini-states based on smaller identities, the definite \& logical result would be the partition of Iraq.

The second danger. It would include the absence of the direct relationship between the state \& its citizen in Iraq. This relationship would be replaced by another indirect relationship between the state $\&$ the individual (Amel, 1989: p. 22). In such pluralistic society, with its many different sects, there is no existence for the individual as a citizen, because the real existence is for the sect, which is considered as the first social unit, \& the state doesn't recognize the existence of the individual unless, he would be affiliating himself with one of these sects.

g). The establishment of any new federal region in Iraq on unilateral bases, beside the federal regional of Kurdistan, would involve the danger of having a system of minorities where there would be no majority to any party or group except through the political or ethnic-sectarian compromise. Those types of policies are temporary in its nature \& unstable, no matter how much it was appraised \& promoted. Its applicability to Iraqi model has proved day by day its weakness, and, its relation to democracy. This could push some Iraqi factions not to oppose, the demands for the formation of such federal units. They believe that, this will create a situation in which the potential for having a majority to confront would be zero, they would become the majority one day \& could play on the Political, Ethnic, Religious \& Sectarian differences, in order to achieve its interests.

Federalism is not always, as some of us mistakenly believe as it is a cause of differences \& conflict \& nor it is a cause for division \& separation, on the contrary, federalism could be exactly the opposite. We believe that, it could be an essential factor in achieving democratic stability, peace \& freedom for the following reasons (Dymond, 2005: pp. 82-94):

1. Federalism is linking with freedom in undeniable form.

2. Federalism considered as the trusted framework to deal with all ethnic \& sectarian conflicts.

3. Federalism plays an important role in enhancing democracy.

4. Federalism provides a better representation of minorities, a catalyst for economic growth.

5. Federalism could achieve reconciliation between ethnicity \& democracy in the states, which have many different ethnic components, making it the ideal treatment to contain the conflict between them.

In light of those reasons, none that has been said above represents an opposing point of view to the federal system per se. Also, does not involve any fear of it. It is just an attempt to alert others, that in the case of Iraq precisely, the application of federal system seems possible or even necessary. But, extending the application of (Regional Federalism) is something different \& involves many threats \& great dangers to Iraq's security, unity, \& survival. Therefore, what seems more appropriate to the situation in Iraq is to expand the scope of the application of the administrative \& not the regional federalism, in that case, we should take into account four basic constants, which are:

First: It is certain that, the adoption of Iraqi's to federalism as a national \& permanent choice, is possible. However, it is a choice where all Iraqis must equally insist on its adoption, apply it on a right, balanced \& persistent bases, which would prevent transforming it to a threatening factor to their interests \& national unity. We could not ignore neither deny the probabilities of the rising conflict among the opinions, interest $\&$ the subidentities of the different political \& social components of Iraq. This could be attributed to a weakness in the unifying national identity, despite the fact that, it has passed more than a decade since the change took place in 2003.

Second: It is certain that, the adoption of Iraqi's to federalism as a national \& permanent choice, should not only aim at achieving the goal of diversity \& plurality within the framework of national unity. In addition, the aim should not be only to guarantee the rights \& freedoms of the ethnic, religious \& sectarian diversified components within the framework of one state, similar to the federal models in Switzerland \& Belgium. Federalism, could also be wanted to achieve liberal democratic goals, including the prevention of the rising of a strong central state heading toward tyranny \& threatening the rights \& liberties of its citizens of the federal units. It also could achieve development through consolidation of resources \& possibilities for the development $\&$ revitaliza- 
tion of the economy, as well as, to achieve security, unification of efforts to achieve self \& bending interests, just like the federal model of USA \& Germany after 1949. In those models, the demands for liberalism, democracy, development \& security were the essential motives more than the demands for diversity \& pluralism within the framework of unity. Iraqi case needs to make a compromise between all the previous motives \& goals in order to succeed (Watts, 2006, Hamilton et al., 1998).

Third: It is certain that, the adoption of Iraqi's to federalism as a national \& permanent choice, is possible. But, it is a choice which could not achieve its goals \& ends, unless it is coupled with democracy. It is considered the guaranteeing condition to achieve the federal goals \& ends. It does that through its recognition to the societal sub-identities, \& the respect to its rights \& constitutional freedoms, and to build a sober economy \& stimulate growth \& development, and to ensure that, the central authority would not move toward authoritarianism. Therefore, the worst of what could happen to a federal state is moving away from democracy, and if that happens, then, we would not get the federalism that ensures for us some or all of those objectives \& not the democracy that grants us the citizenship which ensures for us those rights \& liberties. At the end, only democracy qualifies federalism \& transfers it from political federalism into cultural federalism.

Fourth: It is certain that, the adoption of Iraqi's to federalism as a national \& permanent choice, is possible. However, it is not the only choice to achieve the goals of diversity \& pluralism within the framework of unity through the recognition of the plurality \& diversity of the social component $\&$ the respect to the sub-identities. We believe it could be the last, because the first choice would be a democracy, which is based on the principle of citizenship.

This principle ensures for all the components of the state their unified national identity. It ensures many rights such as, the respect for all the sub-identities, the participation in the whole, active \& equal rights \& duties without any discrimination for any reason. It secures for them the natural rights \& the constitutional liberties in all its forms. Also, it ensures equal opportunities in living, fortune, education, work, free movement inside the state, access to the information, peaceful expression of their ideas, forming associations \& political parties \& the comprehensive participation in the national \& local elections as a voter or a nominee. If all that become available to all citizens, there would be no need for their feeling to add a new constitutional items or making new laws recognizing the existence of the components \& ensure their rights \& liberties. Because, there would not be components in the home \& no minorities need federalism, but citizens their rights and duties are ensured by democracy \& full citizenship without any discrimination. If those constants were based on the coupling of federalism with democracy, then, it would be very natural to conclude that, democracy is a necessity as a basic condition to the success of federal experiment \& its stability \& continuity.

If Iraqis are not going to take into consideration those constants, \& did not recognize what refers to the necessity \& inevitability of the coupling of federalism with democracy, then, it would end up for all of them, no matter what their ethnicity, religions, \& sects, to regret what they have done.

At the end, we believe that, what happened in June 2014 in Iraq, has led to benefits in the interest of the application of the administrative federal system in Iraq through two developments.

The first development is the return of Iraq as a major focus of the concern of the great and big powers. This has been reflected in the formation of the international alliance to fight the ISIS. The United States of America as a leader of this alliance and other members of the alliance are working directly with Baghdad as the federal capital of Iraq. This means that, the Kurdistan federal region must work with the federal government and not independently when it comes to work with the members of the alliance. Such an act is going to increase the common interest between those parties and might lead to solving many legal and political problems obstructing any cooperation between them.

The other important development is, what the specialized U.N. agencies such as the World Bank, the International Monetary Fund, and other specialized agencies doing to Iraq. They have given consultations, professional advice, doing specialized studies on solving Iraq's problems to help the federal government in its efforts to reform corruption in its political, legal, and administrative system, and giving loans under their own administration. Those agencies are working directly with the federal government, and the Kurdistan federal region must cooperate with the federal government in order to secure its $17 \%$ share of those loans.

In conclusion, we believe that, such cooperation between the federal government and the international institutions, would lead to building many federal institutions to run those projects throughout Iraq. Building such institutions would enhance and strengthen the national identity, and the federal government through building common interest among all the administrative, social and political components of Iraq. 


\section{References}

Amel, M. (1989). The Sectarian State. Lebanon: Alfarabi Printing House.

Dymond, L. (2005). Democracy (1st ed.). Baghdad: Dar al-Mamoon.

Hamilton, G. et al. (1998). The Federalist Papers (1st ed.). Translated by Aumran Abo-Hijla, Amman: Dar Al-Farabi for Publishing and Distribution.

Watts, R. L. (2005). Comparing Federal Systems. Kingstan: Institute of Intergovernmental Relations, Queen University.

Submit or recommend next manuscript to SCIRP and we will provide best service for you:

Accepting pre-submission inquiries through Email, Facebook, Linkedin, Twitter, etc A wide selection of journals (inclusive of 9 subjects, more than 200 journals)

Providing a 24-hour high-quality service

User-friendly online submission system

Fair and swift peer-review system

Efficient typesetting and proofreading procedure

Display of the result of downloads and visits, as well as the number of cited articles

Maximum dissemination of your research work

Submit your manuscript at: http://papersubmission.scirp.org/ 